\title{
Interactive comment on "Chemical
} characterization of fine particulate matter emitted by peat fires in Central Kalimantan, Indonesia, during the 2015 El Niño" by Thilina Jayarathne et al.

\section{Anonymous Referee \#2}

Received and published: 8 October 2017

1. Given there are only few measurements of smoke aerosol properties in Maritime Continents (MC), the work presented here surely is timely and highly relevant to the ACP. The paper is missing a body of literature on the work recently done by 7SEAS program in this region, particularly those paper in the 7SEAS' special issue published in Atmospheric Research in 2013. Note, the link between El Nino and fires still remain unclear; what is known in this part of the world is that Hurricane in subtropical Philippines can lead to large fires in Indonesia. This is worth mentioning, as the paper seems to say that it is the El Nino year that made this study interesting - which is not. 
Reid, J., E. Hyer, R. Johnson, B. N. Holben, J. Zhang, J. R. Campbell, S. A. Christopher, L. D. Girolamo, L. Giglio, R. E. Holz, C. Kearney, J. Miettinen, E. A. Reid, F. J. Turk, J. Wang, P. Xian, R. J. Yokelson, G. Zhao, R. Balasubramanian, B.-N. Chew, S. Janai, N. Lagrosas, P. Lestari, N.-H. Lin, M. Mahmud, B. Norris, A. X. Nguyen, N. T. K. Oahn, M. Oo, S. Salinas, and S.-C. Liew, 2013. Observing and understanding the Southeast Asia aerosol system by remote sensing: An initial review and analysis for the Seven Southeast Asian Studies (7SEAS) program, Atmospheric Research , 122, 403-468.

Wang, J., C. Ge, Z. Yang, E. J. Hyer, J. S. Reid, B.-N. Chew, M. Mahmud, Y. Zhang, and M. Zhang, 2013. Mesoscale modeling of smoke transport over the Southeast Asian Maritime Continent: interplay of sea breeze, trade wind, typhoon, and topography, Atmospheric Research , 122, 486-503.

2. Relevant work regarding the importance of smoke aerosol composition on regional climate can be found below. It is important to discuss if the past modeling work in this region, based on your data of smoke optical properties, is good enough or has large uncertainties - likely a huge overestimation or underestimation of smoke absorption? Such discussion is important as the abstract of this manuscript says so, yet the manuscript itself touched very little on the recent modeling work of smoke radiative effects in that region.

Ge, C., J. Wang , and J. S. Reid, 2014, Mesoscale modeling of smoke transport over the Southeast Asian Maritime Continent: coupling of smoke direct radiative feedbacks below and above the low-level clouds, Atmos. Chem. Phys. , 14, 159-174.

3. Finally, the fire emission inventory still has large uncertainty, and it is unclear how the measured results here compare with the results widely used by different inventories. Can we say $\mathrm{OC} / \mathrm{BC}$ ratio uncertainty or variation is a factor of 2 or 3 ? See below several papers and references therein.

Zhang, F., J. Wang , C. Ichoku, E. Hyer, Z. Yang, C. Ge, S. Su, X. Zhang, S. Kondragunta, J. Kaiser, C. Wiedinmyer, and A. da Silva, 2014. Sensitivity of mesoscale

Printer-friendly version

Discussion paper
Interactive

comment 
modeling of smoke direct radiative effect to the emission inventory: A case study in northern sub-Saharan African region, Environmental Research Letter, 9, 075002.

Koppmann, R., K Czapiewski, JS Reid, A review of biomass burning emissions, part I: gaseous emissions of carbon monoxide, methane, volatile organic compounds, and nitrogen containing compounds R Koppmann, K Czapiewski, JS Reid - Atmospheric Chemistry and Physics, 2005.

Reid, J. S., Koppmann, R., Eck, T. F., and Eleuterio, D. P.: A review of biomass burning emissions part II: intensive physical properties of biomass burning particles, Atmos. Chem. Phys., 5, 799-825, 2005.

My recommendation is that the importance of $\mathrm{BC} / \mathrm{OC}$ ratio measured in this paper should be discussed in the context of these past work, so that, as said in the abstract, these measurments are valuable for the emission inventory community and atmospheric modeling community.

Interactive comment on Atmos. Chem. Phys. Discuss., https://doi.org/10.5194/acp-2017-608, 2017. 